\title{
The Internet and Citizen Participation in Rulemaking
}

\author{
Cary CoglanesE*
}

\begin{abstract}
Each year, regulatory agencies promulgate thousands of important rules through a process largely insulated from ordinary citizens. Many observers believe the Internet could help revolutionize the rulemaking process, allowing citizens to play a central role in the development of new government regulations. This paper expresses a contrary view. In it, I argue that existing efforts to apply information technology to rulemaking will not noticeably affect citizen participation, as these current efforts do little more than digitize the existing process without addressing the underlying obstacles to greater citizen participation. Although more innovative technologies may eventually enable the ordinary citizen to play a greater role in rulemaking, such future applications will only raise the question of whether greater citizen involvement is necessarily a good thing. A substantial and systematic increase in citizen comments will not be a welcome development if it leads regulators to strive to satisfy those who file comments instead of selecting the policy option that best fulfills the statutory mandate or public interest. Overall, the novelty of applying information technology to the rulemaking process merits no special optimism. but rather such technology deserves careful assessment of both its positive and negative effects.
\end{abstract}

Every year, unelected officials at government agencies such as the Federal Aviation Administration, the U.S. Department of Agriculture, and the Environmental Protection Agency create thousands of regulations that affect nearly every aspect of social and economic life. ${ }^{1}$ Even though these agency officials each year produce more than fifteen times as many binding laws on society as Congress does, ${ }^{2}$ the

* Visiting Professor of Law, University of Pennsylvania and Chair, Regulatory Policy Program, John F. Kennedy School of Government, Harvard University. I am grateful for helpful comments I received on an earlier draft from Peter Shane, an anonymous reviewer for this journal, and participants in a conference on democracy and digital technology at the Yale Law School. Copyright $\odot 2004$ by Cary Coglianese. All rights reserved. Please address correspondence to the author at the Regulatory Policy Program, John F. Kennedy School of Government, Harvard University, Cambridge, Massachusetts 02138, cary_coglianese@harvard.edu.

${ }^{1}$ Cary Coglianese, E-Rulemaking: Information Technology and the Regulatory Process, 56 ADMIN. L. REV. 353, 354 (2004).

${ }^{2}$ Id. at 358 n. 18 (noting that from 2001-2002 agencies issued 4,153 rules, while Congress enacted 245 statutes). 
agency rulemaking process remains remarkably hidden from the view of the general public. ${ }^{3}$ The relative insularity of a process with dramatic impacts on society stands at odds with ordinary notions of democratic policymaking. Consequently, many lawyers and policymakers look with hope to new information technologies as a way of overcoming rulemaking's democratic deficit.

Just as information technology has transformed aspects of global commerce and everyday life, the Internet also promises to transform the rulemaking process by increasing transparency and enhancing opportunities for public participation. Commentators have argued that the Internet will "change everything" about the dynamics of administrative rulemaking, "revolutionizing public participation" so that ordinary citizens can "play a more central role in the development of new agency policies and rules." Given how digital technologies have made communication easier in other areas of life and how few citizens currently participate in administrative rulemaking, such optimism is understandable.

${ }^{3}$ See Cary Coglianese \& Margaret Howard, Getting the Message Out: Regulatory Policy and the Press, 3 HARV. INT'L. J. PRESS/POL. 39 (1998) (noting the limited coverage the media gives to rulemaking by government agencies).

${ }^{4}$ See, e.g., Beth Simone Noveck, The Electronic Revolution in Rulemaking, 53 EMORY L.J. 433 (2004); Barbara H. Brandon \& Robert D. Carlitz, Online Rulemaking and Other Tools for Strengthening our Civil Infrastructure, 54 ADMIN. L. REV. 1421 (2002); Stephen M. Johnson, The Internet Changes Everything: Revolutionizing Public Participation and Access to Government Information Through the Internet, 50 ADMIN. L. REV. 277 (1998); HENRY H. PERRITT, JR., ELECTRONIC DOCKETS: USE OF INFORMATION TECHNOLOGY IN RULEMAKING AND ADJUDICATION, REPORT TO THE AdMINISTRATIVE CONFERENCE OF THE UNITED STATES (Oct. 19, 1995), available at http://www.kentlaw.edu/classes/rstaud/internetlaw/casebook/ electronic_dockets.htm. For additional material, see the Regulatory Policy Program's erulemaking website at www.e-rulemaking.org.

5 Johnson, supra note 4 , at 303 . The phrase "the Intemet changes everything" was earlier made by former chairman of the Federal Communications Commission, Reed Hundt, in a much broader context. Reed Hundt, Speech at the INET '96 Conference, Montreal, Canada (June 28, 1996), available at http://www.fcc.gov/Speeches/Hundt/spreh629.txt. On the dramatic changes the Internet may portend for government and policymaking, see also GRAEME BROWNING, ELECTRONIC DEMOCRACY: USING THE INTERNET TO INFLUENCE AMERICAN PoLrTICS (1996) (arguing that by allowing citizens access to information and offering an easier means to communicate, the Internet has the "potential to influence not only the course, but the very essence of national politics"); ELAINE CIULLA KAMARCK \& JOSEPH S. NYE., JR., EDS., GOVERNANCE.COM: DEMOCRACY IN THE INFORMATION AGE (2002) (examining an array of potentially sweeping implications of the Internet for democratic governance); Brandon \& Carlitz, supra note 4, at 1422 ("The Internet could fundamentally change how the American public participates in federal policymaking."); Daniel C. Esty, Environmental Protection in the Information Age, 79 N.Y.U. L. REv. 115, 170 (2004) (arguing that "[a]dministrative law especially stands to be transformed by trends toward increased openness" created by erulemaking). 
Nevertheless, despite the allure of new information technologies, their application to the rulemaking process merits a realistic assessment, not just a hopeful embrace. As with any other proposal for institutional or policy change, policymakers should consider whether a particular application of e-rulemaking will help solve a significant public problem or achieve an important goal. Will erulemaking effectuate better or more responsive regulatory policymaking? Even if so, will it create any undesirable consequences? Do the advantages of specific applications of erulemaking overcome their disadvantages?

For many observers, e-rulemaking appears to be obviously desirable, if not inevitable. ${ }^{6}$ In some cases, such optimism will be warranted and new technologies ought to be adopted. Yet in this article, I argue that there will be other cases where careful analysis will counsel against adopting new technologies. Some applications of technology to rulemaking are not likely to alter public participation or government decision-making all that much, while others may prove to be undesirable even if they do help engage the public or make government decision-making more transparent.

Policymakers and public managers should not let the enthusiasm for increased citizen participation and transparency distract them from realistically assessing the effects of different technologies on the public and government. ${ }^{7}$ Decisions about whether and how to use information technology in the rulemaking process are policy choices, not purely technical decisions. In the end, it is quite possible that some applications of information technology should be rejected precisely because they enable too much transparency or public involvement in administrative rulemaking.

In Part I of this article, I review the key avenues for public participation in the rulemaking process and show that few ordinary citizens currently participate in rulemaking. In Part II, I discuss how information technology is beginning to be applied with the aim of increasing citizen involvement in rulemaking and how that technology might be applied in the future in still more innovative ways to enhance

${ }^{6}$ Michael Tonsing, Two Arms! Two Arms! E-Government is Coming!, 51 FEDERAL LAWYER 18-19 (July 2004) (arguing that "it seems inevitable that much good will come of [erulemaking]").

7 See Frederick Schauer, Talking as a Decision Procedure, in DELIBERATIVE POLITICS: Essays ON DEMOCRACY AND DisagReEMENT 17-27 (STEPHEN MACEDo, ED., OXFORd UNIV. PRESS 1999) (urging a realistic assessment of deliberation that includes consideration of its drawbacks and obstacles); Renee A. Irvin \& John Stansbury, Citizen Participation in Decision Making: Is It Worth the Effort?, 64 PUB. ADMIN. REV. 55, 63 (2004) (noting that "it behooves the administrator to consider the advantages and disadvantages of the decision-making process ... bearing in mind that talk is not cheap - and may not even be effective"). 
public participation. In Part III, I emphasize that decisions about applying information technology to rulemaking are policy choices that call for careful consideration of both the positive and negative impacts of e-rulemaking. Specifically, I elaborate on the kinds of effects that e-rulemaking may have on both public participation and government decision-making. Although discerning the effects of e-rulemaking will require careful empirical study in the coming years, I hypothesize in Part IV about some of these effects and argue that the federal government's current e-rulemaking efforts are unlikely to result in any dramatic expansion of citizen participation in the rulemaking process.

\section{Public Participation in the Rulemaking Process}

Technological enthusiasts' "rosy predictions" 8 about the positive impacts of e-rulemaking stem in part from the current low level of citizen participation in the regulatory process. ${ }^{9}$ The way that government agencies issue regulations does not, at least at first glance, look like a robust democratic process. The key decision makers imposing government rules are not directly elected. ${ }^{10}$ Instead, they are only indirectly accountable, having been appointed and confirmed by elected officials who are typically too busy to oversee all of what their appointees do. Moreover, even these appointees themselves rarely write the rules that their agencies issue, but instead delegate the drafting, analysis, and policy design to career civil servants. Key deliberation and decision-making by career staff and political appointees takes place inside the agency, sometimes literally behind closed doors. The vast majority of agencies are headed by a single administrator, so by definition there is nothing comparable to an open town hall meeting or representative debate immediately preceding final regulatory decisions in these agencies.

The Administrative Procedure Act (APA), which provides the legal framework for federal agency rulemaking, does require that agencies at a minimum provide the public with notice of proposed new rules by publishing them in the Federal Register. ${ }^{11}$ They must also

${ }^{8}$ See Johnson, supra note 4 , at 336.

${ }^{9} I d$. at 278 (noting that for many decisions made by regulatory agencies, "citizens are shut out of the decision-making process").

${ }^{10}$ Cornelius M. Kerwin, Rulemaking: How Government Agencies Write LaW and MAKE POLICY 113 (3d ed. 2003) (noting that rulemaking "is conducted by persons with no direct electoral link to any constituency").

${ }^{11}$ Administrative Procedure Act, 5 U.S.C. $\S 553(b)$ (2000). 
give "interested persons" an opportunity to comment on these proposed rules. ${ }^{12}$ By its own terms, however, the APA imposes a rather weak requirement for public participation. It does not require government to engage in any open deliberation with the public or even to adhere to the views contained in any comments submitted by the public. Agencies are given discretion to decide how to allow the public to comment on proposed rules, though the most typical practice is for agencies to allow a defined period (usually of a couple of months) during which members of the public can submit written comments to the agency headquarters. The APA does require agencies to give "consideration" to the "relevant" material submitted by the public, but does not require that they rely on any expressed views of the public as a basis for their decisions.

In practice, of course, the rulemaking process has always been a much more permeable process than a bare-bones account of the APA requirements would suggest. Owing in part to a series of legislative and judicial developments requiring openness and access to information, and in even larger part to political and practical factors, agency officials routinely engage in dialogue with interested persons even outside of the APA's public comment period. ${ }^{14}$ Even in agencies headed by a single administrator, rulemaking often takes place in teams or work groups of staff from different offices within an agency. ${ }^{15}$ It is commonplace for agency staff to meet with representatives from regulated industries, advocacy groups, and state and local government when developing new proposals for regulations. ${ }^{16}$ Agencies also routinely hold workshops and public

${ }^{12}$ See id. at $\$ 553(\mathrm{c})$.

${ }^{13} I d$.

${ }^{14}$ Other legislation has required or permitted agencies to become more transparent and open to public input. Freedom of Information Act, 5 U.S.C. $\$ 552$ (2000); Government in the Sunshine Act, 5 U.S.C. $\$ 552 \mathrm{~b}$ (2000); Federal Advisory Committee Act, 5 U.S.C. app. $\$ 2$ (2000); Negotiated Rulemaking Act, 5 U.S.C. $\$ \S 561-570$ (2000). In addition, the judiciary has demanded that agencies base their policy decisions on reasons supported by an accessible administrative record. Citizens to Preserve Overton Park, Inc. v. Volpe, 401 U.S. 402 (1971); Motor Vehicle Mfrs. Ass'n. of the United States, Inc. v. State Farm Mut. Auto. Ins. Co., 463 U.S. 29 (1983).

${ }^{15}$ See Thomas O. McGarity, The Internal Structure of EPA Rulemaking, 54 LAW \& CONTEMP. PROBS. 57 (Autumn 1991).

${ }^{16}$ See, e.g., KERWIN, supra note 10, at 189 (3d ed. 2003) (noting the extensive and routine contact that takes place during the rulemaking process, often before a proposed rule is issued); Home Box Office, Inc. v. Fed. Communications Comm'n, 567 F. 2d 9, 57 (D.C. Cir. 1977) (describing "informal contacts between agencies and the public [as] the 'bread and butter' of the process of administration"). 
hearings and convene advisory committees or roundtable sessions before issuing new proposed regulations. ${ }^{17}$

Rather than being completely insulated from the political process, agencies find themselves embedded in a web of relationships with individuals and organizations from outside of government, as well as in repeated interaction with congressional representatives and presidential staff seeking to oversee and shape their decisions. ${ }^{18}$ Furthermore, because agency regulations are always subject to repeal or revision by Congress, this possibility of repeal provides another democratic check on decisions made by government administrators. ${ }^{19}$

Notwithstanding the various avenues for holding regulatory agencies accountable, the fact remains that the "public" that participates in the rulemaking process is still a very narrow slice of the entire citizenry. Most citizens, indeed most voters, do not even know about agency rulemaking, let alone participate in it. In one study of more than 1,500 comments filed in about two dozen rulemaking proceedings at the U.S. Environmental Protection Agency, individual members of the public - ordinary citizens - were found to have submitted less than $6 \%$ of these comments. ${ }^{20}$ In contrast, corporations and industry groups filed about $60 \%$ of the comments, and local, state, or federal government officials also filed about $25 \%$, a significant amount. $^{21}$ Other studies confirm that, except for the rare rulemaking, citizens are the least frequent filers of comments in rulemaking. ${ }^{22}$

There are no available data on the proportion of the overall citizenry that files comments in rulemaking, but undoubtedly this is a

${ }^{17}$ Cary Coglianese, Assessing the Advocacy of Negotiated Rulemaking: A Response to Philip Harter, 9 N.Y.U. ENVTL. L.J. 386, 442 (2001) (noting the "individual meetings, public workshops, or formal advisory committees" used by agencies to solicit public input).

${ }^{18}$ See, e.g., Peter L. Strauss, et al., Administrative Law 50 ( $9^{\text {th }}$ ed. 1995) (showing web of institutional interactions in the bureaucratic environment).

${ }^{19}$ The Congressional Review Act of 1996, 5 U.S.C. $\$ \S 801-808$ (2000), now even permits Congress to consider the nullification of rules on a "fast track" basis. On the role of Congress in overseeing regulation, see generally KERWIN, supra note 10, at 213-24.

${ }^{20}$ Cary Coglianese, Challenging the Rules: Litigation and Bargaining in the Administrative Process 48 (1994) (unpublished Ph.D. dissertation, University of Michigan) (on file with author).

${ }^{21} I d$.

${ }^{22}$ See, e.g., Marissa Golden, Interest Groups in the Rule-making Process: Who Participates? Whose Voices Get Heard?, 8 J. PUB. ADMIN. RES. \& THEORY 245 (1998); Ross

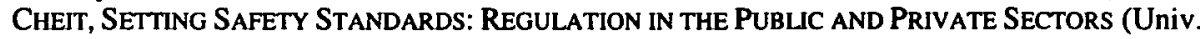
of California Press 1990). 
very low number. According to a survey conducted in 2000 , only about half of all Americans have reported visiting at least one federal agency's website at least once. ${ }^{23}$ According to another survey of randomly selected citizens conducted in the early 1990 s, only $8 \%$ of citizens report having made any "contact" with non-elected federal officials during the past year. ${ }^{24}$ Of these contacts, $62 \%$ were specifically about "particularized concerns" that "pertain only to [the] respondents themselves or their immediate families," such as benefits determinations or tax questions. ${ }^{25}$ These survey data suggest that, as a generous upper bound, certainly no more than $3 \%$ of adults file comments on agency rulemakings; however, the actual percentage is undoubtedly much lower as the survey asked broadly about "contacts" rather than specifically about rulemaking comments. Furthermore, we know that survey responses about other forms of participation, such as voting, typically overstate actual levels of participation. ${ }^{26}$

It is exceedingly clear that the vast bulk of public participation in rulemaking is not coming from "the public" in the broadest sense of the term. Is this a serious problem? To gain some perspective on whether such low levels of citizen participation in rulemaking should be viewed as problematic, we should consider why participation in policymaking is valued. There are generally four main ways of characterizing the value of public participation. ${ }^{27}$

First, public participation can be viewed as a mechanism for expressing individual preferences that the regulatory agency then aggregates and uses as a basis for making its regulatory decisions. This can be thought of as participation as voting.

Second, public participation can be viewed as a process by which individuals engage in a deliberative process that aims toward the achievement of a rational consensus over the regulatory decision. This might be thought of as participation as deliberation.

${ }^{23}$ Darrell M. West, E-Government and the Transformation of Service Delivery and Citizen Attitudes, 64 PUB. ADMIN. REV. 15, 22, 27 (2004).

${ }^{24}$ SidNey Verba, Kay Lehman Schlozman \& Henry E. Brady, VoICE aNd EQuality: Civic Voluntarism IN AMERICAN Politics 56 (Harvard Univ. Press 1995).

${ }^{25}$ Id. at $57-58$.

${ }^{26}$ Id. at $50 \mathrm{n} .2$ ("As is always the case in surveys, ... reports of voting are exaggerated.").

${ }^{27}$ For a cogent elaboration of the first three of these four perspectives, see John Elster, The Market and the Forum: Three Varieties of Political Theory, in FOUNDATIONS OF SOCIAL Choice Theory 103 (John Elster \& AANUND Hylland, EDS., Cambridge Univ. Press 1986). 
Third, public participation can be viewed as intrinsically valuable for citizens themselves, for such participation fosters important personal virtues. This is participation as citizenship.

Finally, public participation can be viewed as valuable because it helps provide government decision makers with additional information needed to make better decisions. The drafters of the APA appear to have had something like this in mind, advising agencies that when selecting among different ways of involving the public "[t]he objective should be to assure informed administrative action." 28 This is participation as information. ${ }^{29}$

The low level of participation by ordinary citizens, especially relative to participation by industry groups, is problematic from any of these four perspectives. From the standpoint of participation as citizenship, low participation means few individuals are using rulemaking to cultivate or exhibit the virtues of citizenship. Low citizen participation can also mean that the preferences, ideas, and facts represented in the regulatory process will be either limited or skewed. Whether from the vantage of participation as voting, deliberation, or information, the sheer lopsidedness of participation is problematic, because so many voices are heard from industry and so few from ordinary citizens.

\section{TECHNOLOGICAL OPTIONS FOR INCREASING CITIZEN PARTICIPATION}

If we accept, for any of these reasons, that the low level of citizen participation in rulemaking is problematic, the next step is to search for ways of increasing participation. E-rulemaking's enthusiasts urge solutions that make use of the Internet, arguing that new information technologies will increase the ordinary citizen's knowledge of, access

${ }^{28}$ AtTorney General's ManUal on the Administrative Procedure Act 31 (1947).

${ }^{29}$ See Office of the Vice President, Accompanying Report of the National PERFORMANCE REVIEW: IMPROVING REgULATORY SYSTEMS (1993) (hereinafter IMPROVING REGULATORY SYSTEMS), available at http:/govinfo.library.unt.edu/npr/library/reports/ reg04.html ("Earlier and more interactive public participation ... provides information otherwise unavailable to the agency); KERWIN, supra note 10, at 159 (discussing how agencies acquire information through public participation in the rulemaking process); Cary Coglianese, Richard Zeckhauser \& Edward Parson, Seeking Truth for Power: Informational Strategy and Regulatory Policy, 89 MINN. L. REv. 277 (2004) (showing how regulators must act strategically to garner participation by industry in order to secure needed information).

${ }^{30}$ Mariano-Florentino Cuéllar, Public Engagement in the Administrative State: A Financial Privacy Case Study (2004), available at http://papers.ssm.com/sol3/papers.cfm? abstract_id=485063. 
to, and involvement in rulemaking. ${ }^{31}$ Of course, not all applications of information technology can be expected to have the same effects. Each application will deserve its own separate consideration, but we can distinguish between at least two broad sets of technological options for increasing citizen participation. ${ }^{32}$ The first set includes options that digitize the current rulemaking process by making use of the Internet to post agency dockets on the web and allowing comments to be submitted by email. The second set of options include more innovative uses of technology that would most likely change the existing rulemaking process in significant ways. After describing these two sets of options in this Part, I will turn in the next Part to what policymakers should consider in deciding whether to adopt any of these options and how researchers can evaluate their impacts on participation and rulemaking.

\section{A. Digitizing THE EXISTING PROCESS}

In recent years, a number of agencies have constructed websites containing rulemaking documents and have allowed citizens to submit comments electronically. ${ }^{33}$ For example, the Department of Transportation stores all documents related to rulemaking in an electronic docket that is accessible to everyone via the Internet. ${ }^{34}$ In the 1990s, the U.S. Department of Agriculture allowed citizens to submit e-mail comments on a proposed regulation for the labeling of organic foods - and subsequently, the agency received more than 250,000 comments. $^{35}$ Other agencies have begun to establish chat rooms or other online dialogue venues in connection with specific regulatory initiatives. ${ }^{36}$

${ }^{31}$ See supra notes 5-6; infra note 39.

${ }^{32}$ For a similar distinction in types of e-government developments, see West, supra note 23 , at 17, 21 (delineating four stages of e-government and concluding that "current usage [of information technology] has not produced dramatic changes or much evidence of the fourth stage of e-government - interactive democracy").

${ }^{33}$ See Brandon \& Carlitz, supra note 4 , at 1433 . For a list of such agency websites, see http://www.archives.gov/federal_register/public_participation/rulemaking_sites.html.

${ }^{34}$ See U.S. Department of Transportation, Docket Management System, http://dms.dot.gov/.

${ }^{35}$ Stuart W. Shulman, An Experiment in Digital Government at the United States National Organic Program, 20 AGRIC. \& HUM. VAL. 253, 255 (2003).

${ }^{36}$ See, e.g., Thomas C. Beierle, Democracy On-Line: An Evaluation of the National Dialogue on Public Involvement in EPA Decisions, Resources for the Future Report (Jan. 
Congress has supported efforts to digitize agency rulemaking. In 2002, Congress adopted the E-Government Act, ${ }^{37}$ which among other things creates a new Office of Electronic Government. Both Democratic and Republican Administrations have also embraced the use of information technology in rulemaking. The Clinton Administration's National Performance Review urged regulatory agencies to use information and communication technology to connect citizens more closely to government rulemaking. ${ }^{38}$ The Bush Administration's e-government agenda specifically includes a plan to increase e-rulemaking efforts by federal agencies. ${ }^{39}$ As the first step in that plan, the Bush Administration launched a government-wide portal, Regulations.gov, to help citizens locate and submit electronic comments on any proposed agency regulation. ${ }^{40}$ The second step, currently underway, involves the creation of a government-wide online regulatory docket system.

Through these efforts, government is digitizing existing rulemaking practices. Government seeks to lower the costs to citizens of obtaining information about rulemaking and providing input into regulatory decision-making. If current efforts succeed in achieving this goal, we could then expect to see an increase in the number, and

2002), available at http://www.rff.org/rff/Documents/RFF-RPT-demonline.pdf; Brandon \& Carlitz, supra note 4, at 1431-33.

${ }^{37}$ E-Government Act of 2002, Pub. L. No. 107-347, 116 Stat. 2899.

${ }^{38}$ IMPROVING REGULATORY SYSTEMS, supra note 29 (recommending that agencies explore the use of information technology in rulemaking to enhance public access to and participation in the regulatory process).

${ }^{39}$ Press Release, Office of Management and Budget, OMB Outlines New Federal EGovernment Strategy (Oct. 25, 2001), available at http://www.whitehouse.gov/omb/ pubpress/2001-54.html; Press Release, Office of Management and Budget, OMB Accelerates Effort to Open Federal Regulatory Process to Citizens and Small Businesses (May 6, 2002), available at http://www.ksg.harvard.edu/cbg/Conferences/rpp_rulemaking/OMB_Opens_ Reg_Process.pdf.

${ }^{40}$ For further information about Regulations.Gov, see Cindy Skrzycki, US Opens Online Portal to Rulemaking, WASH. POST Jan. 23, 2003, at E01; Rick Otis, e-Rulemaking, Presentation at conference at Harvard University (Jan. 22, 2003), available at http://www.ksg.harvard.edu/cbg/Conferences/rpp_rulemaking/Otis_Presentation.pdf; Oscar Morales, A Status Report on the Administration's E-Rulemaking Initiative, Presentation at conference at American University (Jan. 8, 2004), available at http://www.american.edu/academics/provost/rulemaking/morales.htm; Noveck, supra note 4; U.S. General Accounting Office, Electronic Rulemaking: Efforts to Facilitate Public Participation Can Be Improved, GAO-03-901 (Sept. 17, 2003), available at http://www. ksg.harvard.edu/cbg/rpp/erulemaking/papers_reports/GAO\%20Report\%209.17.03.pdf. 
perhaps quality, of comments filed by citizens in agency rulemaking proceedings.

\section{B. NEW USES OF Digital TECHNOLOGIES}

In addition to current efforts to digitize existing practices, information technology could be used in the future to transform the rulemaking process or add new features to it that more fully exploit developments in such technology. ${ }^{41}$ Over time, advances in technology can be expected to give rise to proposals to change current administrative procedures in order to enhance the public's access to and involvement in rulemaking. The following four examples represent reasonably feasible proposals that might very well loom on the not-so-distant horizon.

1. Regulatory Polling. Agencies' current approach to public participation is largely reactive, with regulators issuing proposals and waiting for members of the public to submit comments on them. With the diffusion of Internet access throughout society, it will become easier for agencies to be more proactive and reach out to solicit public comment. One proactive approach would be to conduct opinion polling in connection with proposed regulations. In some cases, agencies already engage in survey research when they conduct contingent valuation studies that seek to determine how to monetize various non-market values. Contingent valuation studies typically ask a random sample of the public questions about the amount they would pay for incremental reductions in risks or increases in amenities (such as how much it is worth to them to preserve a pristine wilderness or protect the visibility of the Grand Canyon). ${ }^{42}$ Such studies have their limitations, a practical one being the current expense of administering surveys. ${ }^{43}$ Yet, to the extent that online technologies make polling less costly to administer in the future, regulatory agencies may well consider using such polling on a more widespread basis.

${ }^{41}$ Coglianese, supra note 1 , at 363-71.

${ }^{42}$ For discussions of contingent valuation research, see Richard T. Carson, Nicholas E. Flores \& Norman F. Meade, Contingent Valuation: Controversies and Evidence, 19 ENVTL. RES. ECON. 173 (2001); James K. Hammitt, Valuing Mortality Risk: Theory and Practice, 34 ENVTL. SCI. \& TECH. 1396, 1398 (2000); W. Michael Hanemann, Valuing the Environment through Contingent Valuation, 8 J. ECON. PERSP. 19 (1994); Maureen L. Cropper \& Wallace E. Oates, Environmental Economics: A Survey, 30 J. ECoN. LTT. 675, 700-21 (1992).

${ }^{43}$ Another obstacle, of course, is securing approval for such surveys under the Paperwork Reduction Act, 44 U.S.C. $\$ \S 3501-3521$ (2000). 
2. Commenting via Simulation. Advances in information technology make it more feasible for agencies not only to direct polling questions to members of the public, but also to provide greater guidance and structure when seeking public feedback. Using something akin to what Keith Belton has termed an "on-line calculator" (or in a more sophisticated version, something akin to a SimCity ${ }^{\circledR}$ game), regulatory agencies could provide public access to simulation software based on the agency's modeling and assumptions. ${ }^{44}$ Members of the public could modify parameters in the agency's model (such as the stringency of the regulatory standard, frequency of risks, and so forth) and then run different simulations to determine the benefits and costs of the regulation. Such an approach may enable regulatory agencies to capture more deliberate public opinion about key tradeoffs the agency faces in crafting a new regulation.

3. Virtual "Juries." Another option would be to use information technology to convene regulatory "juries." Digital technology could be used to replicate the kind of face-to-face deliberation in traditional juries. $^{45}$ Through such juries, agencies could charge randomly selected groups of citizens with making the core value judgments implicit in regulatory decision-making. For example, when setting new air quality standards, an environmental agency needs to make tradeoffs between marginal increases in health benefits and the corresponding costs of complying with the new standards. The environmental agency implicitly faces a value choice of how much human lives saved or asthma cases avoided are worth. At present, regulatory officials make these decisions based on their own analysis and judgment, sometimes without even acknowledging that they are making such choices. ${ }^{46}$ With the aid of information technology, agencies could make these decisions more openly by facilitating a process that could lead to a "verdict" by a random group of citizens. These regulatory juries may still not make the ultimate regulatory decision, but they could provide agencies with a basis for key assumptions and value choices by answering a series of specific interrogatories. As most federal regulatory agencies are headquartered 8-9.

${ }^{44}$ Keith B. Belton, What If Everyone Were a Policy Analyst?, REgulation, Fall 2000, at

${ }^{45}$ Another face-to-face parallel is the process of deliberative polling. See JAMES S. FISHKIN, THE VOICE OF THE PEOPLE: PUBLIC OPINION AND DEMOCRACY 161-76 (1995).

${ }^{46}$ See Cary Coglianese \& Gary Marchant, Shifting Sands: The Limits of Science in Setting Risk Standards, 152 U. PA. L. REV. 1255 (2004); Wendy E. Wagner, The Science Charade in Toxic Risk Regulation, 95 CoLUM. L. REV. 1613 (1995). 
in Washington, D.C., information technology could be used to connect citizens from across the country and perhaps even allow them flexibility to participate in deliberations while fitting their "jury duty" around work schedules. Agencies could communicate via digital technology to educate members of the jury on relevant technical issues and present competing arguments that can form the basis for deliberation. Chat rooms could then provide a forum for virtual deliberations by these regulatory juries.

4. Enhanced Digital Transparency. In addition to facilitating online deliberation, digital technology will make it easier to store agency communication and information in ways that make it easily accessible to the public. Already, the Bush Administration is working to create a government-wide system for online regulatory dockets that contain all documents that form the basis for new regulations. ${ }^{47}$ However, using digital technology, it will be increasingly feasible to take still further steps to make the rulemaking process even more transparent. Consider two possibilities:

- James O'Reilly has recently proposed that agencies should make available the internal drafts of an agency's new regulations, i.e., those drafts that were presented to a political appointee at the agency but then were later modified before the rule became final. ${ }^{48} \mathrm{He}$ argues that disclosure of earlier drafts would help those who need to interpret agency regulations, offering clues about why a final rule reads as it does, much as legislative history may help with statutory interpretation. One could imagine that agencies will be able to provide easily a clear history of its rulemaking drafting, utilizing a feature such as the "track changes" function on Microsoft Word ${ }^{\circledR}$.

- After an agency has issued a proposed rule and before the agency issues its final rule, secret communications between government officials and those outside of government have been generally viewed with suspicion. In the well-known Home Box Office ${ }^{49}$ decision, the D.C. Circuit Court of Appeals criticized the Federal Communications Commission and its members for holding secret conversations with industry officials, holding that when such ex parte communications take place following the publication of a proposed rule, agency officials must place a

${ }^{47}$ Coglianese, supra note 1 , at 364-65.

${ }^{48}$ James T. O'Reilly, Let's Abandon Regulatory Creationism: The Case for Access to Draft Agency Rules, 28 ADMIN. \& REG. L. NEWS 4 (Spring 2003). 1977).

${ }^{49}$ Home Box Office, Inc. v. Fed. Communications Comm'n., 567 F.2d 9, 57 (D.C. Cir. 
summary of the conversation in the agency docket. Although the $H B O$ holding has been narrowed, if not repudiated, by subsequent courts, ${ }^{50}$ many agencies have still adopted internal practices that discourage ex parte communications and require summaries of such communications in their regulatory dockets. ${ }^{51}$ Summarizing conversations has seemed a reasonable strategy, but advances in digital technology now make it feasible for agency staff to go further by creating digital recordings of their ex parte communications (whether in person or on the telephone) and loading digital audio files of these recordings onto the agency's online docket. Imagine clicking a link on the Department of Labor website and downloading a RealPlayer ${ }^{\circledR}$ file to hear a conversation that took place, say, between the OSHA Administrator and the head of the National Association of Manufacturers over a key decision in a new worker safety regulation. Although no agency has yet to go to this length, this type of total transparency is now a technological possibility.

These four ideas - (1) simulations, (2) polling, (3) juries, and (4) digitization of drafts and ex parte communications - provide an indication of the range of innovations that could be introduced by agencies in the future. ${ }^{32}$ As Jeff Lubbers has written, new information technologies could make possible "nothing less than . . a transformation of the rulemaking process as a whole." ${ }^{, 53}$

${ }^{50}$ United Steelworkers of America, AFL-CIO-CLC v. Marshall, 647 F.2d 1189 (D.C. Cir. 1980), cert. denied, 453 U.S. 913 (1981) (declining to apply ex parte requirement in Home Box Office to OSHA notice-and-comment rulemaking); Sierra Club v. Costle, 657 F.2d 298 (D.C. Cir. 1981) (declining to follow Home Box Office requirement in EPA notice-andcomment rulemaking).

${ }^{51}$ STRAuSS ET AL., supra note 18, at 1056 (9th ed. 1995) (noting that "the general approach of HBO has been widely adopted, without legislative or judicial enforcement, by agency rulemakers"); Ashley C. Brown, The Duty of Regulators to Have Ex Parte Communications, The EleCTriCrTy JouRnal, Mar. 2002, at 10-14 (discussing constraints that regulatory agencies have imposed on themselves with respect to ex parte communications).

${ }^{52}$ Even more dramatic, less centralized processes of regulation will probably be contemplated in the future. Joseph S. Nye, Jr., Information Technology and Democratic Governance, in GOVERNANCE.COM: DEMOCRACY IN THE INFORMATION AGE 9 (ELAINE CIULla KaMarCK \& JoSEPH S. NYE, JR., EDS., 2002).

${ }^{53}$ Jeffrey S. Lubbers, The Future of Electronic Rulemaking: A Research Agenda 2 (Regulatory Policy Program, Working Paper No. RPP-2002-04, 2002), available at http://www.ksg.harvard.edu/cbg/research/rpp/RPP-2002-04.pdf. 


\section{TRACKING E-RULEMAKING's EFFECTS}

We have seen that digital technologies open up new, even potentially dramatic, possibilities for informing the public and involving citizens in the rulemaking process. For those who are accustomed to shopping or banking online, allowing citizens to participate in rulemaking online may well seem an obvious if not desirable choice. $^{54}$ No matter how obvious, any decision about the design of the rulemaking process is itself a policy choice. ${ }^{55}$ As a result, decisions about options ranging from online dockets to regulatory juries merit careful consideration. Just as some have suggested that the Internet might contribute to the fragmentation of civic life even as it expands information, ${ }^{56}$ information technology in the rulemaking process might also create, in varying degrees, both negative effects as well as positive ones.

Before deciding to adopt new technologies, whether to digitize the existing process or transform it, policymakers and public managers should consider carefully the effects of different technological options on the rulemaking process. ${ }^{57}$ Will citizen participation increase? Will the relevant goals of participation be furthered? Will there be any offsetting consequences that arise? In general, we can conceive of two main categories of effects that policymakers should consider and researchers should study: (1) effects on public participation, and (2) effects on government officials and their decision-making.

\section{A. EFFECTS ON PUBLIC PARTICIPATION}

Effects on members of the public could occur along any number of potential dimensions. As such, policy analysis should go beyond general claims that a new application of information technology will "improve public participation" and instead consider concrete changes

54 See Tonsing, supra note 6, at 19.

5s The positive political economy literature has taught us well how structural or procedural design can have important policy ramifications. See, e.g., Terry Moe, The Politics of Bureaucratic Structure, in CAN THE GOVERNMEnT GOVERn? (JOHN ChUBB \& PAUL PETERSON, EDS., 1989).

${ }^{56}$ See, e.g., CAss Sunstein, RePublic.com 51-62, 71 -5 (Princeton Univ. Press 2001).

${ }^{57}$ For a related discussion in connection with other reforms to the administrative process, see Cary Coglianese, Empirical Analysis and Administrative Law, 2002 U. ILL. L. REV. 111 (2002). 
that might be induced. Some of the specific types of potential change include:

Mobilization. Do more people get involved in the rulemaking process?

Distribution. Is there any change in the kinds of people who participate? E-rulemaking efforts might well increase the total number of participants in the rulemaking process, but the distribution across types of participants - e.g., corporations versus ordinary citizens - could still remain the same.

- Frequency. Do specific individuals and organizations participate more frequently? If participation increases overall, how much is due to an increased number of participants versus an increase in the frequency of participation by the same participants?

Knowledge. Is learning enhanced or inhibited? Do people get exposed to new or contrary views?

Tone. Does the tone, style, emphasis, or sophistication of expression change?

- Ideas. Do the ideas generated by the public, or the views that they express, change? Are views arrayed differently along the ideological spectrum? Do they convey new or better information? Are the ideas more complex or simpler?

- Conflict. Are conflicts mitigated or exacerbated? Which kinds of issues seem to generate reduced or heightened conflict?

- Perceptions. How do people feel about their participation and their engagement with others in the rulemaking process? Do they view the government any differently (such as with different levels of perceived trust, legitimacy, or approval)?

Spillovers. Are there any effects that spill over into other policy forums or into other aspects of politics? Does the process tend to polarize the public?

- Organization. How, if at all, do the roles of political organizations like trade associations, unions, or public advocacy groups change? Does easier and more direct access to the rulemaking process diminish the value of "gatekeeper" organizations? Will such groups adapt to fill different roles? 
With such an array of possible effects on those outside of government, it will be important to specify precisely what effects are desired when using e-rulemaking to improve public participation.

\section{B. EFFECTS ON GOVERNMENT DECISION-MAKING}

Effects on government decision-making will also be arrayed along a number of dimensions. Some of the specific changes to government agencies that e-rulemaking might induce include:

- Time. Does the process take more or less time from the beginning to the time the agency issues its final rule?

Cost. Does the process demand more staff time and analysis? Greater participation seems likely to increase the time for listening, reading, and responding to public input. ${ }^{58}$

- Response. How do government officials respond to public input? Do they view it as constructive or as a burden? Do they become more focused on responding to those who participate than on fulfilling their statutory mandate or serving the interests of the broader public?

- Role. Do government officials perceive their role as a decision maker any differently? Does e-rulemaking diminish or alter their perceived role as expert decision makers?

- Agency Deliberation. Will changes that make government processes more transparent make it easier or more difficult for officials or staff to deliberate among themselves? To contact experts for advice? To obtain adverse information from industry?

- Outcomes. Are decisions improved? Are behaviors changed and conditions in the world improved relative to the status quo?

As long as regulatory officials remain the ultimate decision makers when it comes to setting regulatory policy, the impact of technology on their decision-making will also remain one of the ultimate tests for e-rulemaking. ${ }^{59}$

${ }^{58}$ See, e.g., Jim Rossi, Participation Run Amok: The Costs of Mass Participation for Deliberative Agency Decisionmaking, 92 Nw. U. L. REV. 173 (1997).

${ }^{59}$ See Coglianese, supra note 1 , at 386 (noting that the ultimate test for e-rulemaking will be whether it makes any improvement to government regulation). 


\section{WILL E-RULEMAKING REALLY WORK, AND WOULD THAT NECESSARILY BE A GOOD THING?}

Different e-rulemaking proposals will result in varied effects along the numerous dimensions just enumerated. This is why it will be important to specify the goals of e-rulemaking clearly and monitor the effects of different technological options in terms of these goals. If the goal is to increase the level of participation so that more citizens will practice civic virtues, rather than to increase the quality of deliberation or policy decisions, then decision makers can properly focus on the volume and frequency of participation. Yet, if the goal is to improve the quality of deliberation or provide better information, then more participation is not necessarily better. ${ }^{60}$ Generating more comments that say little will not add much new information. Furthermore, if the goal combines multiple objectives, then policymakers should take various different kinds of effects into consideration, recognizing that the pursuit of one objective may sometimes come at the expense of others. $^{61}$

Of course, discerning the actual effects of e-rulemaking will require careful empirical evaluation undertaken after agencies have decided to use new technologies in the rulemaking process. Although any verdict on e-rulemaking must therefore await further study made after the passage of additional time, at this point it is possible to offer some hypotheses about the likely effects of the two types of erulemaking efforts discussed in Part II. In brief, contrary to stated presidential and congressional goals, the extant research literature would suggest that current efforts to digitize the existing rulemaking process will be unlikely to lead to any dramatic overall increase in citizen participation in rulemaking. Some of the more innovative and transformational ideas discussed in Part II will stand a greater chance of significantly enhancing citizen voices in the rulemaking process. However, these more dramatic changes to the rulemaking process may well have other, less desirable effects on rulemaking and therefore will raise the question of whether the increased citizen participation they could produce would be desirable.

Current efforts to digitize the rulemaking process are supposed to increase participation by making it easier for ordinary citizens to

${ }^{60}$ A recent study by Bill West, for example, showed that public comments filed in rulemaking proceedings actually contribute relatively little new information. William F. West, Formal Procedures, Informal Processes, Accountability, and Responsiveness in Bureaucratic Policy Making: An Institutional Policy Analysis, 64 PUB. ADMIN. Rev. 66, $71-72$ (2004).

${ }^{61}$ See Coglianese, supra note 1 , at $378-80$ (discussing tradeoffs between different goals for e-rulemaking). 
access information about policy proposals and communicate their ideas to government officials. ${ }^{62}$ Congress's stated aim in passing the E-Government Act was "to promote use of the Internet and other information technologies to provide increased opportunities for citizen participation in Government."63 In describing his administration's egovernment initiative, President George W. Bush announced that, "our goal is to make your government more accessible to all Americans." "64 In developing both Regulations.gov and the new online docket system, the Bush Administration's key priority has been to "mak[e] it easier for citizens and businesses to participate in the regulatory process."

Although current efforts will almost certainly make it easier at the margin for the ordinary citizen to monitor and participate in rulemaking, these efforts are unlikely to decrease the costs of participation sufficiently to generate substantial changes in the median or modal level of citizen participation in rulemaking. Admittedly, electronic communication does make it easier for a large number of citizens to submit comments on highly salient rules, ${ }^{66}$ but citizen voices will likely remain sparse in the overwhelming majority of agency rulemakings. It was not surprising that, in the first several

${ }^{62}$ See supra Part II.A.

${ }^{63}$ E-Government Act of 2002, Pub. L. No. 107-347, 116 Stat. 2899.

${ }^{64}$ Letter from President George W. Bush on the Launch of the New FirstGov Web Site (March 14, 2002), available at http://www.whitehouse.gov/news/releases/2002/03/ 20020314.html.

${ }^{65}$ Memorandum from Mitchell E. Daniels, Jr. to the Heads of Executive Departments and Agencies, on Redundant Information Systems Relating to On-Line Rulemaking Initiative (May 3, 2002), available at http://www.whitehouse.gov/omb/pubpress/2002-27.pdf; see also eRulemaking Fact Sheet: The President's E-Government Initiative (describing the "ultimate goal" of e-rulemaking in terms of "allow[ing] the public to access and search all publicly available regulatory material [and] provid[ing] an easy and consistent way for the public to search, view and comment on proposed rules"), available at http://www.regulations.gov/images/eRuleFactSheet.pdf; Kimberly T. Nelson, Assistant Administrator and Chief Information Officer for the U.S. Environmental Protection Agency, Statement Before the Committee on Government Reform 2 (March 24, 2004) ("The eRulemaking initiative will help overcome barriers to public participation in the federal regulatory process by improving the public's ability to find, view, understand, and comment on regulatory actions."), available at http://reform.house.gov/UploadedFiles/EPA\%20Egov\%20test_Mar_24_2004.pdf.

${ }^{66}$ A very select number of rules in the past have generated tens of thousands of comments, sometimes facilitated in part by the use of electronic communication. See, e.g., Shulman, supra note 35 (describing high volume of comments in USDA's organics rulemaking); KERWIN, supra note 10, at 194 (describing high volume of comments in Bureau of Land Management rangelands rule). See also supra note 35 and accompanying text. 
months after the Bush Administration launched Regulations.gov, only about 200 comments had been submitted through this otherwise highly publicized web portal. ${ }^{67}$ During this period, only about 8 of the EPA's approximately 300,000 public comments and 21 of the DOT's 18,000 comments were submitted through Regulations.gov. ${ }^{68}$

To be sure, over time more people should become aware of Regulations.gov and we should expect to see more comments submitted through it. Nevertheless, even after both Regulations.gov and the new government-wide docketing system are fully on-line, the core obstacles that keep citizens from participating in rulemaking will still remain. It takes knowledge and effort to participate in rulemaking. Even with the Internet, it still takes time to file a comment. Yet we know that many citizens do not even take the time to participate in a still more common and familiar process: voting. Engagement in elections, the most visible form of political participation, has declined since $1960 .^{69}$ In 2000 , only slightly more than half of the voting age public cast ballots in the presidential election $^{70}$ - a voting rate lower than in other developed countries. ${ }^{71}$

${ }^{67}$ U.S. General Accounting Office, Electronic Rulemaking: Efforts to Facilitate Public Participation Can Be Improved, GAO-03-901 23 (Sept. 17, 2003), available at http://www.ksg.harvard.edu/cbg/rpp/erulemaking/papers_reports/GAO\%20Report\%209.17.03 .pdf.

${ }^{68}$ Id. at $23-24$.

${ }^{69}$ Voter interest and involvement in elections has been widely thought to have declined over the past four decades. See Paul R. Abramson \& John H. Aldrich, The Decline of Electoral Participation in America, 76 AMER. POL. SCI. Rev. 502 (1982); R. TEIXEIRA, THE DISAPPEARING AMERICAN VOTER (The Brookings Institution 1992); THOMAS E. PATTERSON, The VANishing Voter: Public InVolvement IN AN AGE of UnCERTAINTY (Alfred A. Knopf 2002). But see Michael P. McDonald \& Samuel L. Popkin, The Myth of the Vanishing Voter, 95 AMER. POL. SCI. REv. 963 (2001) (finding a less substantial decline in tumout since 1960 after re-calculating the voting-eligible population to exclude felons and non-citizens but also to include overseas citizens). There is mixed evidence about trends in citizen contacts with public officials. Compare Steven J. Rosenstone \& John Mark Hansen, Mobilization, PARTICIPATION, AND DEMOCRACY IN AMERICA (MacMillan 1993) (reporting a decrease in the percentage of citizens writing members of Congress) with VERBA, SCHLOZMAN \& BRADY, supra note 24 , at $72-73$ (reporting that citizens' communication with state and national officials over public policy issues increased from $11 \%$ to $22 \%$ between 1967 and 1987).

${ }^{70}$ Federal Election Commission, Voter Registration and Turnout 2000, available at http://craig.dynup.net/voting/Voter_Registration_and_Turnout_2000.pdf (last visited December 10,2004$)$. Only slightly more than two-thirds of registered voters actually voted. Id.

${ }^{71}$ VERBA, SCHLOZMAN, \& BRADY, supra note 24, at 69 (noting that "the United States lags far behind other democracies when it comes to voting turnout"). For other studies of voting levels, see RAYMOND E. WOLFINGER \& STEVEN J. ROSENSTONE, Who Votes? (Yale Univ. Press 1980); G. Bingham Powell, Jr., American Voter Tumout in Comparative Perspective, 80 Amer. Pol. SCI. Rev. 17 (1986); LAWRENCE LeDuc, Richard Niemi \& PiPPA 
To participate in rulemaking, citizens need to understand the rudiments of the rulemaking process, if only to know that agencies issue proposed rules and open themselves up to receive public comments for a designated period of time. ${ }^{72}$ Citizens need to be able to understand what the agency is proposing and must be able to have some understanding of the underlying policy issues involved in the rulemaking. The issues in most rulemakings, though, are technical and complex, which is largely why Congress has delegated such decisions to regulatory agencies. However, according to the latest findings from the U.S. Department of Education, about 90 million adults (or over half of all adults in the U.S.) "experience considerable difficulty in performing tasks that required them to integrate or synthesize information from complex or lengthy texts." ${ }^{, 73}$ While agencies should certainly strive to display information clearly and in easy-to-read formats, simply digitizing existing paper records will not by itself make the rulemaking process much more accessible for most ordinary citizens.

Even for those citizens with sufficient skill to process information about rulemaking, it takes time to learn about what agencies are doing or proposing to do. Citizens either need to be already well-informed about regulatory agencies' work or must actively monitor or research what agencies are doing. Contrast this with what it takes for a citizen to vote in a presidential election. Presidential campaigns spend millions of dollars actively seeking out voters through political advertising. The media also provide extensive coverage to elections. Citizens simply need to know where to vote and how to cast their ballot - and political campaigns also spend large amounts of time and money to get voters to the polls. In contrast with voting, rulemaking requires that citizens do some investigating on their own in order to participate. It is difficult to see many citizens going to much effort to learn about rulemaking. On the contrary, it seems Americans are

Norris, eds., Comparing Democracies 2: New Challenges in the Study of Elections and Voting (SAGE PUBlications 2002).

${ }^{72}$ As one participant in a recent e-rulemaking focus group noted, it is "insufficient simply to post information on the Web, since the rulemaking process and its imperatives [are] unfamiliar to many citizens." Stuart W. Shulman, The Internet Still Might (But Probably Won't) Change Everything: Stakeholder Views on the Future of Electronic Rulemaking 31 (2004), available at http://erulemaking.ucsur.pitt.edu/doc/reports/e-rulemaking_final.pdf.

${ }^{73}$ Irwin S. Kirsch et al., Adult Literacy in America: A First Look at the Findings of the National Adult Literacy Survey xvii (3d ed. April 2002), available at http://nces.ed.gov/ pubs93/93275.pdf. 
tuning out news in general - let alone the few specialized stories that appear about administrative agencies.?

Even those individuals who have the capacity or incentive to follow what agencies do often fail to get involved in rulemaking. In 2003, Peter Strauss surveyed members of the American Bar Association's Section on Administrative Law and Regulatory Practice. $^{75}$ He found that $55 \%$ of the 320 lawyers who responded had not filed any comments in rulemaking proceedings in the past three years. $^{76}$ If the majority of the most relevant legal specialists do not file comments in rulemakings, we probably should not expect to see a large proportion of ordinary citizens filing comments, even with a more digitized and accessible rulemaking process.

To ensure citizens' voices play a much more significant role in most rulemakings, policymakers will probably need to turn to more innovative and transformational uses of information technology than those currently being implemented. Some of the new uses of technology discussed in Part II would likely fare better than existing proposals in enhancing citizen involvement. This is because, even when digitized, the existing notice and comment framework takes a reactive approach to public participation. Agencies that wait for citizens to submit comments will not receive many. On the other hand, technology-aided processes such as regulatory juries or simulations are more likely to make a difference because they reach

${ }^{74}$ S.E. Bennett, S.L. Rhine \& R.S. Flickinger, The Things They Cared About: Change and Continuity in Americans' Attention to Different News Stories, 1989-2002, 9 HARV. INTL. J. PRESS/POL. 75 (2004). Coverage of regulatory policy making by mainstream media outlets has tended to be relatively sparse. R. Jeffrey Smith, Covering the EPA, or Wake Me Up If Anything Happens, Colum. Journalism Rev., Sept./Oct. 1983, at 29; John Gravois \& Walt Potter, How the Press Misses the Beat, WASH. JouRnAlism Rev., Jan./Feb. 1982, at 29; Jules Witcover, Washington's Uncovered Power Centers, ColuM. JouRnalisM REV., Mar./Apr. 1972, at 14. Media scholars explain the inattention to regulatory issues by pointing to the complexity of regulatory issues and the need to spend "endless hours in musty archives." STEPHEN Hess, THE WASHINGTON REPORTERS 52 (The Brookings Institution 1981). See also Coglianese \& Howard, supra note 3, at 40-41 (discussing the difficulties journalists face in covering the regulatory beat). One effect of e-rulemaking will be to make it easier for journalists to cover rulemaking, so it is possible that e-rulemaking will lead to more extensive media coverage of rulemaking issues. Of course, even if it does have this effect, if Americans continue to exhibit declining attention to the news, increased media attention may still matter relatively little in activating broad citizen participation in rulemaking.

${ }^{75}$ Peter L. Strauss, The ABA Ad Law Section's E Rulemaking Survey, ADMIN. \& REG. L. NEws, Spring 2004, at 8; also available at http://www.ksg.harvard.edu/cbg/rpp/erulemaking/ papers_reports/Strauss_Erulemaking_Survey.pdf.

${ }^{76}$ Id. at 8 . 
out to citizens, educate them about the relevant regulatory issues, and proactively solicit citizens' input."

In addition, technologies used in novel ways to bring more transparency to rulemaking - such as through digitized recordings of ex parte communications - will likely have more substantial effects than existing efforts. Even if relatively few citizens follow or participate in rulemaking, public officials who know that the general public can easily see and hear everything they do will almost certainly act differently than they do now. On an optimistic view, such technologically induced transparency might lead political appointees and career public servants to make decisions that better serve the broad public interest over special private interests.

Yet we need not be too optimistic about even these more innovative uses of information technology. Total transparency may make government officials more circumspect, but it could also make them excessively risk averse. Furthermore, total transparency will almost certainly inhibit regulators' ability to gather necessary information and test out new ideas, to the detriment of developing sound public policy.

Greater participation through more innovative forms of erulemaking may well mean that, as Daniel Esty has written, "[p]eople with good ideas - even those who never get to Washington or their state capitals - ... have a chance to shape policy outcomes."79 But if so, it would also mean that those with less accurate or helpful ideas would have a chance to shape those outcomes. Greatly expanding participation could very well exacerbate cognitive cascades and tendencies toward groupthink that can afflict policy deliberations. ${ }^{80}$

There is also the risk that systematic and substantial increases in citizen comments would shift regulators' attention away from selecting the policy option that best fulfills their statutory mandate or the public interest, and instead lead regulators to strive to satisfy the views expressed by those who file comments. ${ }^{81}$ This problem would move

${ }^{77}$ For an elaboration of one such idea, see Cuéllar, supra note 30.

${ }^{78}$ For the argument that total transparency would severely constrain government regulators ability to make well-informed decisions, see Coglianese, Zeckhauser, \& Parson, supra note 29.

${ }^{79}$ Esty, supra note 5, at 170.

${ }^{80}$ See Cass R. Sunstein, Group Judgments: Deliberation, Statistical Means, and Information Markets (Aug. 2004) (unpublished manuscript, available at http://papers.ssrn. com/sol3/papers.cfm?abstract_id=578301).

${ }^{81}$ For discussion of the role of citizen satisfaction in policymaking, see Derek Bok, Measuring the Performance of Government, in Why People Don'T TRust Government 55 
the process closer to making rules by plebiscite, which will risk giving undue prominence to expedient or even erroneous considerations. As Peter Strauss has noted, "it is not hard to imagine manipulative campaigns exploiting the tools of spam to proliferate comments dramatically."

Efforts to increase citizen participation through e-rulemaking will need to tread carefully so that those judgments that regulatory agencies are charged with making on the basis of scientific or technical expertise do not become displaced by decision-making by plebiscite. On the other hand, when policy decisions require making value judgments that have not been predetermined by an underlying statute, as they frequently do, then citizens' preferences can provide a reasonable basis for making these value choices. ${ }^{83}$ In such cases, technology could help by making it easier for regulators to estimate social preferences using Internet surveys of large, representative samples of the public.

If structured well, then, e-rulemaking might help enhance the democratic legitimacy of administrative rulemaking. However, to structure e-rulemaking well requires explicit analysis of how well different technological applications will solve specific problems or advance concrete goals relative to other options (including the status quo). ${ }^{84}$ Simply because new types of information technology can make possible new forms of public participation or new administrative procedures, this does not necessarily mean that we ought to deploy all of these technologies. Some uses of e-rulemaking may turn out not to fare much better than the status quo. Other uses of technology, though, may well increase citizen participation, in which case policymakers will need to consider whether other, less desirable consequences could also arise from that increased participation. The

(JoSEPH S. NYE, JR. ET AL., EDS., HARVARD UnIV. PrESS 1997; Cary Coglianese, Is Satisfaction Success? Evaluating Public Participation in Regulatory Policymaking, in THE PROMISE AND Performance of Environmental Conflict Resolution 69 (Rosemary O'Leary \& Lisa BINGHAM, EDS., 2003).

${ }^{82}$ Strauss, supra note 75 , at 10.

${ }^{83}$ For example, an environmental agency's experts may identify health effects associated with exposure from varying levels of air pollutants, but scientific evidence of these health effects cannot determine at what level an air quality standard should be set. Setting such a regulatory standard would call for making a value judgment about how much risk to human health is acceptable and how much costs should be tolerated in achieving a given level of health protection. See Coglianese \& Marchant, supra note 46.

${ }^{84}$ See Cass R. Sunstein, Paradoxes of the Regulatory State, 57 U. CHI. L. REv. 407-08 (1990) (noting that "evaluation of regulatory controls and legal doctrines must depend in large part on their effects in the world"). 
future challenge for e-rulemaking mirrors what has been the fundamental challenge running throughout administrative law: how to design procedures and institutions that strike an appropriate balance between law, democratic politics, and expert judgment.

\section{CONCLUSION}

Recent advances in information technology have led many observers to predict that the Internet will lead citizen voices to be heard more loudly in the government conference rooms and offices where regulatory decisions are made. Digital technologies do make feasible new agency practices that can make the rulemaking process more accessible to those who seek to follow and participate in it. Digital technologies also promise new opportunities for citizens to communicate and interact with government officials, and raise possibilities for transforming existing rulemaking procedures so as to involve the public in still more central ways.

As attractive as some applications of digital technology undoubtedly seem, designers of regulatory processes should keep in mind the credo of designers and engineers everywhere: Decisions should be based on an evaluation of how well each available option fares in terms of relevant goals, constraints, and effects. New procedures made possible by information technologies deserve consideration, but this newness itself merits neither optimism nor skepticism. Instead, it calls for careful, dispassionate analysis.

Finally, whenever they do decide to add new technologies to the rulemaking process, government officials should ensure opportunities to collect data and learn more about the kinds of effects these technologies have on citizens and policymakers. To learn from erulemaking, we will need more empirical research investigating what difference, if any, information technology makes both in citizen behavior and in how government agencies develop rules.

${ }^{85}$ See Christopher F. EDLEY, JR., AdMINISTRATIVE LAW: RETHINKING Judicial Control of Bureaucracy 13-29, 222-5 (Yale Univ. Press 1990). 
